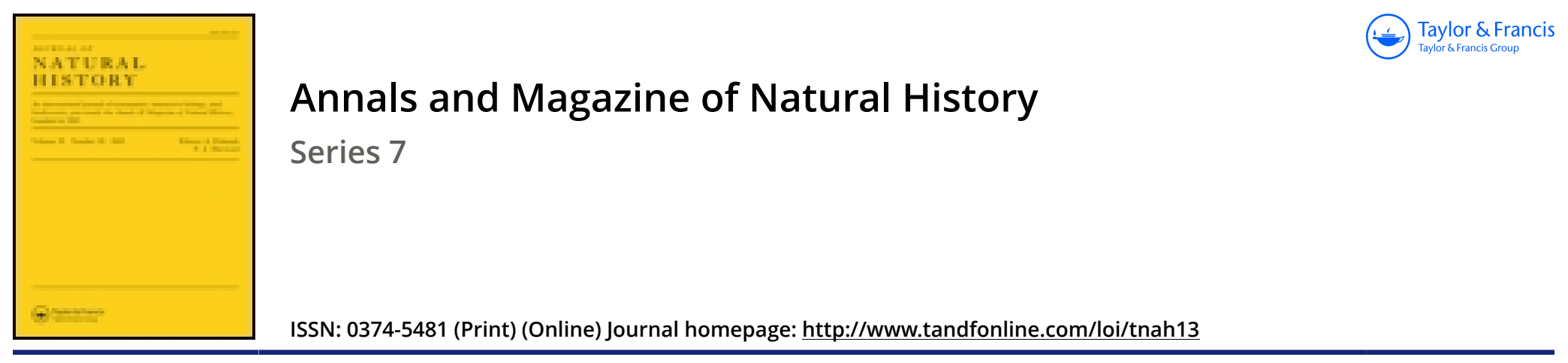

\title{
XLVI.-Descriptions of genera and species of Coleoptera from South Africa
}

\section{H.S. Gorham F.Z.S.}

To cite this article: H.S. Gorham F.Z.S. (1901) XLVI._Descriptions of genera and species of Coleoptera from South Africa, Annals and Magazine of Natural History, 7:40, 349-365, DOI: 10.1080/00222930108678483

To link to this article: http://dx.doi.org/10.1080/00222930108678483

$$
\text { 曲 Published online: } 29 \text { Sep } 2009 .
$$

Submit your article to this journal $\sqsubset$

Џ Article views: 3

Q View related articles $\square$

Citing articles: 1 View citing articles $\square$ 


\section{Mustela Guatkinsii (Horsf.).}

Martes Gwatkinsii, Horsf. Cat. E. Ind. Coll. p. 99 (1851) ; Blyth, J. A. S. B. vol. xxvi. p. 316 (1858).

The whole animal, except the chin and throat, very dark brown. Hair long and coarse, soles of the feet hairy; the ears are wanting in the light margin characteristic of the other species. Chin white, throat deep yellow; there is on either side a dark spot in line with the mouth and about midway between its corner and the base of the ear.

The skull differs in several points from that of $M$. flavigula, althongh it is clearly allied to that species and agrees with it in the shape of the posterior molar.

In its general shape it is greatly flattened, especially over the eyes, and it hardly rises at all over the brain-case; the auditory bullæ are also somewhat flattened, and the meatus in consequence rather shorter and less conspicuous.

It further differs from the skulls of all the other species in the absence of the first premolar, and, judging by the distance between the second premolar and the canine, this does not seem to be an individual variation.

There is a second skull in the Museum collected in the Nilgiris by Mr. Davison which agrees in every respect with the type.

Dimensions (from skin):-Head and body 350 millim.; tail 300.

Skull: greatest length 82 ; basal length 78 ; zygomatic breadth 50 ; least breadth at postorbital constriction 22 ; least palatal breadth between carnassials 13 .

$H a b$. Peninsula of India.

Type o ad., B.M. 79.11.21.621. Madras. Collected by sir W. Elliot, and presented through Col. Sykes to the Indian Museum.

\section{XLVI.-Descriptions of Genera and Species of Coleoptera}

from South Africa. By H. S. GorHAM, F.Z.S. \&c.

[Continued from vol. v. p. 94.]

SINCE the first part of this paper was printed I have received a further collection from Mr. Guy A. K. Marshall, in which are many interesting species not contained in his first collection, of which I now give an account, as well as of the other families (the Coccinellidæ \&c.) sent to me. Of some of the Ann. \& Mag. N. Hist. Ser. 7. Vol. vii. 
obscurer species of this family I have had the advantage of Herr J. Woise's opinion, which is referred to in its proper place.

Some of the Melyridæ here described cannot be at once referred to their proper genera. The South-African members of this subfamily, including those described by former authors, will require entire revision, the reception of them into existing genera, as Anthocomus and Attalus, being always a matter of doubt.

The following are the localities referred to under the numbers given in the first part of this paper:-

Dolichopsis auronitens, Gorh. Ann. \& Mag. Nat. Hist. 1900, v. p. 74 .

Mashonaland, Salisbury (sweeping Jan. 1895).

Opetiopalpus rubricollis, Kl., Gorh. tom. cit. p. 75.

Natal, Frere (under dried cow-dung).

Ichthyurus sp.?, Gorh. tom. cit. p. 85.

Mashonaland, Salisbury (not Natal).

Promecolanguria Marshalli, Gorh. tom. cit. p. 87.

Natal, Frere.

Promecolanguria trogositoides, Gorh. loc. cit.

Mashonaland, Umgesi Spruit, near Charter.

Amblyscelis nigrinus, Gorh. tom. cit. p. 88.

The two higher numbers, Mashonaland, Salisbury (in fungi).

Ancylopus nigrofuscus, Gorh. tom. cit. p. 93.

Mashonaland, Salisbury, Makabusi River (under floodrubbish). Not Natal.

Lycus rostratus, Linn.

Mashonaland, Salisbury.

Lycus subtrabeatus, Bourg.

Mashonaland, Salisbury (Marshall).

Lycus sp., Gorh. tom. cit. p. 84.

Cape Colony, Uitenhage.

Calopteron ruficolle, Bohem. Ins. Caffr. i. fasc. ii. p. 438.

Hab. Natal, Malvern, Karkloof (Marshall). 


\section{Telephorus teter, sp. n.}

Niger, opacus, pube brevi cinerea vestitus; antennis corporis longituline; prothorace subquadrato, basin versus patello angustito, late canaliculato; elytris subtilitor crebre ragosis, subcoriaceis.

Long. 5.5 millim.

\section{Hab. Natal, Malvern (Marshall).}

Antennæ in the male (?) a little longer than the body, very thin, the basal joint stout, equal in length to the third, the second very short, the fourth to the eleventh about equal in length and nearly twice as long as the third. In the femalo the antennæ are shorter by about the length of a joint.

That this species is very near to Cantharis nigrina, Bohem., I have no doubt, but the description of the thorax as "by half shorter than its breadth" in that insect seems to to to point to a different species, as here the length and breadth are about equal; moreover, Boheman makes no mention of the distinct but broad impression which runs the whole length of the thorax. The front angles are a little thickened and plicate, the sides very narrowly reflexed; the front margin is little reflexed. The elytra are a little more shining than the head and thorax. The whole insect is deep black, including the palpi, which Boheman says in C. nigrina are "nigropiceis."

Two examples.

\section{Fam. Cleridæ.}

Subfam. TILLIDEs.

[Clerus] sanguinalis, Westw.

[Clerus] sanguinalis, Westw. P. Z. S. 1852, p. 36, t. xxv. fig. 7.

The genus of this insect is doubtful. It is placed under "Lissaulicus" in Lohde's Catalogue, but has little in common with $L$. lavis, Waterh.

I believe it to be the same as Macrotelus sanguineus, Th., and Aphelochroa carneipennis, Quedenf., is perhaps a synonym. But our insect has the apex of the antennæ concolorous and the femora all red except at the knees, and therefore does not altogether agree with Westwood's deseription.

Hab. Mashonaland, Salisbury.

\section{Graptoclerus, gen, nov.}

Tarsi sat lati, artieulo primo brevi superne discreto, haud bilobato, articulis secundo, tertio et quarto bilobatis valde lamellatis, 
unguiculis simplicibus, basi vix dentatis: capite prothoraceque rugose punctatis, hoc in medio subdilatato. Oculi modice granulati, vix emarginati, transversi. Antennæ graciles ; clava triarticulata, laxe formata; articulis haud transversis, ultimo ovato, apice compresso acuminato. Palpi maxillares apice subulato, labiales articulo ultimo securiformi.

Corpus longius pilosum.

I propose the above for several species of South-African Cleridx, some of which have been described by Boheman and others as "Clerus," but which differ entirely from the American species now referred to that name. They belong to the subfamily of Tillides, the joints of the tarsi being all visible from above. They are not Philocali, differing in the form of the antennæ and of the thorax. With Thanasimus they have much in common in general appearance, but to any one comparing this insect with $T$. formicarius the most radical differences (apart from the critical one of the basal joint of the tarsi) will appear, notably the short antenna with abrupt three-jointed lax club, the thorax with subtubercular smooth interspaces, the elytra uniformly punctured from the base to apex, the fasciæ not clothed with scales, \&c. ; the claws scarcely widened at their bases nor dentate, and feebler.

For type I propose to take the species I now describe as Graptoclerus signatus, and I provisionally associate with it two other species which Mr. G. A. K. Marshall has sent.

\section{Graptoclerus signatus, sp. n.}

Niger, capite prothoraceque obscure sanguineis, creberrime subrugose punctatis, hoc antice posticeque constricto, disco hic illic læri, spatiis lævibus parum tumidis; elytris fasciis duabus albis haud eburatis, anteriore paullo arcuata et obliqua, prope basin nec suturam nec marginem attingente, posteriore communi, pone medium, recta, integra; antenuis rufis, basin versus et apice ipso dilutioribus.

Long. $7 \cdot 5$ millim.

Hab. Mashonaland, Salisbury (Marshall).

'I'he head is thickly, confluently, and subrugosely punctured, obscurely red, covered with long hairs, and the eyes have hairs. The thorax is nearly as wide as the elytra and of equal width with the eyes; it is constricted in the usual way in front and much rounded in to the base, which is margined; its disk is rugosely punctured and there are smooth uneven spaces a little raised. The whole of the elytra are densely and confluently punctured, without any series, and the yellow-white fasciæ are equally punctured. 


\section{Graptoclerus equestris.}

"Clerus" equestris, Boheman, Ins. Caffr. i. fasc. ii. p. 498.

Hab. Mashonaland, Salisbury (Marshall).

Two specimens agree with the description of this insect. I had not seen it before; with the following species and several others it will require a new genus for its reception.

They were found at Salisbury in September 1898 " on Mosasa."

Although this is a very much smoother insect than the one I describe as G. signatus, it will be properly placed in the same genus. The general characters of the antennæ, tarsi, and claws, the form of the thorax and its smooth interspaces, and the punctuation of the elytra without series are the same.

\section{Graptoclerus quadripunctatus, sp. n.}

Ochraceus, crebre, confluenter, elytris distinctius punctatis, his maculis duabus in singulis, nec suturam nec marginem attingentibus, nigris.

Long. 6 millim.

Hab. Natal, Malvern, Umkomaas River (Marshall).

This insect so much resembles Opilo (Clerus) nodicollis, Bohem., that it might readily be confounded with it. The form of the thorax, however, is quite different. The head and thorax are closely and rugosely though not very coarsely granulate-punctate, and hence appear dull. The thorax is broader than long, much rounded behind, and margined at its base; behind the anterior constriction there is a smonth, slightly elevated ridge, interrupted in the middle, and other smooth interspaces further back, especially in the middle, one before the base forms a sort of imperfect carina. The elytra are thickly and confluently and more coarsely punctured. There is a black transverse spot before the middle, and another rounder and larger one about one quarter before the apex.

The antennæ are thin, as in $G$. signatus, their third to eighth joints elongate-fusiform, gradually shortening; the ninth to eleventh form a lax elongate clab, of which the ninth joint is elongate, the tenth is obconic, not much longer than wide, the apical joint is ovate, acuminate, and compressed at the tip. The maxillary palpi have the apical joint transversely cup-shaped and obliquely articulated.

Two specimens, and one received from M. Thery without special locality. 


\section{Prosy mnus, Laporte de Castelnau.}

Prosymnus, Laporte de Castelnau, Silb. Rev. vol. iv. 1836, p. 51. Ryparus, Spin. Mon. Cler. ii. p. 73 (1844).

\section{Prosymnus villosus, sp. n.}

Brunneus; capite prothoraceque creberrime, subrugose, confluenter, elytris grosse rugose punctatis, omnium longius tomentosis ; antennis eapitis prothoracisque longitudine; ore, corpore subtus femoribusque nigro-brunneis; antennarum articulis tertio et quarto quam secundus sesqui longioribus, articulis 5-8 secundo subæqualibus, tribus ultimis clavam laxam prebentibus, ultimo ovato. Long. 6-8 millim.

Hab. Mashonaland, Salisbury (Marshall).

Obscure brown above, the thorax a shade more darkly so than the elytra; the head and thorax are so densely clothed with long upright hairs that the punctuation is seen with difficulty, except where the pubescence is worn off; it is then seen to be quite thick, granular, and often confluent; the interstices are shining. The thorax is nearly as broad as the elytra at their base; its sides are finely margined and reflexed, but this can only be seen when the hairs are worn off. The elytra are evenly covered with large variolose pits, with rugose interstices, often confluent, without arrangement. The underside is darker, pitchy brown, obsoletely and not deeply punctured; the femora are dark, but the trochanters and parts of the abdomen, the trophi, the tibia, and tarsi are ferruginous. In two examples all the body and the whole of the legs are pale rusty red.

Three examples.

That this insect is allied to Ryparus tomentosus, Spin., is obvious; that it is distinct is, I think, equally certain. The colour, the length of the joints of the antennæ, and the punctuation are different both from the description and the figure; in the latter the third joint of the antenna is shown as rather shorter than the second, whereas in $P$. villosus it and the fourth are half as long again, while the whole antenna is much longer proportionally in our insect. Besides this, numerous points of difference exist. 'That it is different from Prosymnus cribripennis, Lap., it would be impossible from his short description, or that in Klug (Cler. p. 394), to tell; but the difference in locality justities me in the belief that it will be found to be so.

In the Munich Catalogue and in Lohde's Catalogue recently published these names are given as synonyms, on what ground I know not, as the insects are of great rarity in 
collections. Spinola did not think his species would prove even congeneric, but he relied on the grooving of the femora, a very common character which occurs in a greater or less degree in other genera of Necrobiides and Enopliides, and would very probably have not been mentioned by Laporte.

It is, however, more probable that the species are distinct. Before makers of catalogues place specific names as synonyms, they should satisfy themselves that some competent specialist has had both insects before him and at the same time.

\section{Hydnocera punctipennis, Bohem.}

Hydnocera punctipennis, Bohem. Ins. Caffr. i. fase. ii. p. 511.

I have already (Trans. Ent. Soc. 1877, p. 260) remarked that Hydnocera is an essentially Anerican genus. The Eastern species prove on examination to have a wholly different antennal structure, and have been separated under the name Neohydnus; and while I admit that I cannot at present discover good characters by which the present insect might be generically separated, yet I feel confident such will be found, unless the insect can be considered not truly endemic.

Two examples sent by Mr. Marshall appear to be identical with this; but the tarsi are darker than Boheman's description would lead one to expect, and in one at least are nearly black.

I believe they were captured at Salisbury; 4990,6896 .

Opetiopalpus rubricollis, $\mathrm{Kl}$.

Opetiopalpus rubricollis, Kl., Gorh. Ann. \& Mag. Nat. Hist. 1900, v. p. 75.

The locality for these examples is Natal, Frere, under dried cow-dung.

Opetiopalpus caffrarius, sp. n.

Niger, elytris cyaneis, antennis pedibusque testaceis, tarsis ad apicem infuscatis; capite prothoraceque creberrime, minute, elytris a basi ultra medium fortiter seriatim fere grosse punctatis, inde lævibus.

Long. 3 millim.

Hab. Mashonaland, Salisbury (Marshall).

The head and thorax are black, inclining to be pitchy, and with the whole body are densely covered with floccose pile; they are densely punctured, so as to be dull; the elytra are shining, dark blue, and with series of very large oblong 
punctures reaching from the base beyond the middle. The antennæ are fuirly long for this genus, entirely yellow, and the legs are also yellow, only the tarsi being infuscate.

Two examples of this species were sent. It is not very like any Opetiopalpus known to me.

\section{Fam. Melyridæ.}

Attalus ridens, sp. n.

Attalum ornatipennem referens, latior, elytrorum lateribus magis explanatis. Læete flavus, elytris basi et lunula postica lata nigris. o. Long. 4 millim.

Mas, elytris ad apicem lamina elevata hamata instructis, apice ipso invaginato et emarginato.

\section{Hab. Natal, Old Umtali (Marshall).}

The head, prothorax, legs, and apex of the elytra and abdomen are of a rich ferruginous red; the margin of the thorax from the front angles and at the base is a little expanded and is whitish yellow; the head is shining; the antennæ red and serrate, as in $A$. ornatipennis. The elytra are expanded and obsoletely bicostate, more distinctly punctured than in A. ornatipennis, the lateral margins a little thickened and reflexed. The humeral callus is raised and prolonged obliquely backwards as an indistinct carina. The broad basal spot on each is contracted at the suture and the margin; the posterior lunule is wide and reaches to the reflex edge of both the suture and margin.

Two specimens, both males.

Obs. This species is easily discriminated by the red head and by the posterior lunule showing no sign of forming a ring.

$$
\text { Attalus? albofasciatus, sp. } \mathrm{n} \text {. }
$$

Elongatus, piceus, submetallico-nitens, nigro-pubescens, ore, antennarum basi, tibiis tarsisque sordide flavis; elytris fascia communi ante medium apiceque albidis. Caput sat magnum, oblongum, antice profunde foveolato-canaliculatum, palpis nigris; antennis filiformibus, capit is prothoracisque longitudine, hoc quam caput haud latiore, basi paullo producto, margine reflexo albescente; pedes longi, tarsis longis (feminæ?), quinque-articulatis. Long. $2 \cdot 25$ millim.

Hab. Natal, Malvern (Marshall).

This insect is probably not an Attalus; but the two examples before me being apparently females, they may conveniently be placed there till the sexes are known. They differ from the type of that genus in being hairy all over. The 
antenna are not long and are scarcely serrate, fuscous, with the basal half pale, but touched with fuscous above for the first two or three joints. 'The head is large and long for the size of the insect and the mouth produced. The thorax is long and narrow, the base obviously produced, so as to lap over the base of the elytra, yet not as in Charopus; its surface is uneven and there is a vague fovea in the middle of its base. The elytra are very thickly set with long black hairs, but are yet quite shining, irregularly and thickly punctate, subcoriaceous, soft in texture; in one example white at their apex, in the other the apex is concolorous. The white fascia extends a little on both sides, at the margins, and suture. The femora and tibix are clothed with long pubescence. The body beneath is fuscons, the tip of the abdomen (where it is not covered by the elytra) is rusty red.

I consider it better to describe this insect than to leave it undescribed, because (1) I cannot be certain that one or both are not males, (2) because by the characters given it is easily to be recognized, (3) because it is, as I think, plainly not described by Boheman, nor to be placed in either of the genera quoted by him.

\section{Attulus? lugens, sp. n.}

Elongatus, totus niger, nitens; elytris pube brevi cinerea vestitis; ore producto; capitis fronte depressa, inter oculos breviter profunde canaliculata ; prothorace oblongo-quadrato, basi haud producto, marginibus reflexis ; elytris perobsolete subeoriaceis.

Long. 2.25 millim.

\section{Hab. Mashonaland, Salisbury (on Mosasa, Marshall).}

This little insect is in form similar to A. albofasciatus, and, like it, is doubtfully of this genus; it is, however, clearly congeneric with that species, but is less hairy. At first sight it is very like a small Malthodes, and, indeed, at first I was inclined to believe it to be a member of the 'l'elephoridæ. The antennæ are, however, inserted well in front, almost at the apex of the rostrate part of the head. The tarsi are very thin, and apparently the claws are simple and without pads. The small size and entirely black colour, if the exception is made of the pitchy second joint of the antennæ, will cause this species to be easily recognized.

Three examples.

\section{Anthocomus felix, sp. n.}

Statura A. ridentis, læte flarus; capitis basi, prothoracis ritta (maris latiore), elytrorum basi et macula subapicali subquadrata, meso- 
et metasterno pedibusque posticis nigris, his geniculis tarsisque flavescentibus.

Long. $4 \cdot 5$ millim. of $q$.

Hab. Mashonaland, Salisbury, Aug. and Sept., on Mosasa (Marshall).

Mas, occipite carinula $\mathbf{V}$ simulante impressa pone carinulam fossulatam; antennis acute serratis.

Femina, antennis brevioribus subserratis ; fronte plana.

Head black in the male, except the mouth and portion in front of the eyes; in the female only the base behind the eyes black; antennæ yellow, becoming slightly fuscous at the tip. Thorax with the front margin straight, the sides and base rounded in one uniform curve, the margin very narrowly reflexed, with a black obconic vitta, with its vertex on the base in the male (in the female this is only represented by an indefinite line), impressed with a wide and rather irregular fossa in front, which in the female is very indefinite. 'The elytra are rather broad, evenly rounded at the apex, and with no difference in the sexes, except that in the male they do not cover the last three segments of the abdomen, each with two blue-black spots, the basal one irregular on the apical side and occupying the whole base, the subapical one is large and squarish, but yet rounded on its apical side. The breast is black, but the abdomen and head beneath are red. The apical segments of the abdomen in the female in the middle, the extreme apex in the male, are black above. The legs are yellow, but the posterior pair are black, with only the trochanters and knees pale.

T'wo specimens.

This pretty Anthoconus is coloured something like Attalus ridens here described; the absence of the overlapping joint of the tarsus in the male will prevent its being taken for a member of that genus.

\section{Chalicorus? formicarius, sp. $\mathrm{n}$.}

Niger, antennarum basi, tibiis tarsisque anticis et intermediis flaris, illis basi infuscatis; prothorace elongato, basi valde constricto depressoque, antice convexo, nigro, basi albido-flavo; eiytris ovatis valde convexis, parce griseo pilosis, profunde seriatim punctatis, nitidis.

Long. 2 millim.

Hab. Natal, Malvern (Marshall).

Head with the eyes wider than the thorax, minutely but distinctly punctured; antennæ filiform, fuscous at the apex, 
yellow for abont four joints at the base; palpi black; thorax compressed laterally, nodiform, much constricted and depressed at the base, the basal portion white; elytra inflated, very deeply and rather coarsely impressed, with elongate punctures, and with very widely scattered but long upright hairs. Legs long, tarsi all five-jointed, the hinder tarsi especially long.

I have placed this species provisionally as a Chalicorus because it is clearly allied to and congeneric with Chalicorus collaris, Boheman; but I have not yet seen any species agreeing with the insect described by Erichson as C. vinulus, which appears to have the elytra not inflated, and therefore I think it doubtful if Boheman's species are to be associated with it.

This very curious little species is almost as perfect an antmimic as the Ceylonese Myrmecospectra. It has altogether the facies of a small ant. The illusion is heightened when the insect is viewed laterally, the pale portion of the thorax then appearing to be a node.

Three specimens were sent me by Mr. Marshall, of which I cannot state the sex.

\section{Hapalochrus mashunus, sp. $\mathrm{n}$.}

Niger, superne obscure cyaneus, parum nitidus, cinereo-pubescens ; capite parcius punctato, nitido ; antennis nigris, paullo serratis; prothorace nirido, ad latera obsolete punctato, ante basin transversim impresso ; elytris creberrime coriaceo-punctatis, corpore inîra cum pedibus nigro.

Long, vix 5 millim. o 9 .

Mas, tibiis anticis apicem versus excisis, intermediis valde incrassatis, infra medium profunde excisis.

Hab. Mashonaland, Salisbury (Marshall).

'I'his Hapalochrus is at once distinguished from any described species by the size, colour, and black antennæ and legs. Very similar species (undescribed) are in my collection from Mozambique and Zanzibar, but differ in not being clothed, as this is, with pubescence, and in the punctuation. The antennæ are simply serrate and are nearly alike in both sexes.

Three specimens, two of them males, were obtained by Mr. Marshall by sweeping in December 1898.

\section{Hapalochrus cerosus, sp. n.}

Niger, superne æneus vel cupreo-micans, parcius pukescens; elytris cupreis vel æneo-viridibus; capite crebre, prothorace ad basin et 
ad latera crebre punctatis; elytris crebre, distincte, subcoriace punctatis ; antennis, pedibus et corpore infra nigris.

Long. 5 millim. $\delta$ o .

Mas, tibiis anticis ad apicęm excisis et torquatis, intermediis infra medium incrassatis et excisis.

Hab. Mashonaland, Lesapi River (Marshall).

Allied to H. mashunus; a very little larger, and appears a little more robustly built. The head is very much more coarsely but yet closely punctured; the antennæ are similar, but more robust; they are feebly serrate, and alike in both sexes. 'The thorax is like that of H. mashunus, but more coarsely punctured; in both species it is wider than long. The elytra are also similar, but more coarsely punctured, the punctures are often confluent and are evenly spread over the whole surface; the pubescence is grey and not distinct, unless viewed sideways.

Three examples were sent, obtained in November 1897.

\section{Hedybius variicornis, Bohem.}

Hedybius variicornis, Bobem. Ins. Caffr. i. fasc. ii. p. 467.

Hab. Mashonaland, Salisbury (Marshall).

Two examples (a male and a female) are probably to be referred to this; but the measurements given by Boheman seem too small; our male measures 5 millim. and the fernale $4 \frac{1}{2}$. The structure of the head is also not well expressed if our insect be identical, as it is not only "uneven, with the front deeply impressed on each side," but it has the buccal portion yellow, raised into a semicircular ridge in front of the eyes, and with an elevation projecting backwards into the cavity; the whole occiput, which is black, is excavated, and with two or three black, setiform, elevated spines. The antennæ have the first two joints spotted with black above and the third to the sixth joints yellow, the remainder fuscous. The head of the female is bifossulate; only the second joint is spotted, the fifth to the end joints fuscous, and the whole antenna shorter than in the male; the tarsi in the fomale are also blackish.

Notwithstanding these slight discrepancies I think this insect is H. variicornis, Bohem.

\section{Iledybius albipennis, sp. $\mathbf{n}$.}

Pallide flarus, antennarum articulis tertio ad apicalem superne fusco-lineatis (maris tribus ultimis fuscis); prothorace valde transverso, lateribus subangulatis, immaculato; elytris albis, 
nigro-pilosellis, crebre, fortiter et confluenter punctatis; corpore subtus cum pedibus flavo ; epimeris, meso- et metathoracis nigromaculatis.

Long. $65-7$ millim. o 9 .

Mas, antennis sesquilongioribus, ad apicem magis infuscatis ; capitis vertice lamina transversa irregulari utrinque subinvoluta, occipite ab oculis fortiter excavato, in medio quasi bicarinato, postice elevato plano.

Femina, antenuis brevioribus, occipite plano magis nitido.

Hab. Mashonaland, Salisbury (Marshall).

This very curiously coloured Hedybius is wholly unlike any described from South Africa, but is allied and very similar to H. lividus, Gorham, from Abyssinia. The structure of the head is unlike that of either of the three species described by me in these 'Annals' (cf. tom. cit. pp. 80,81), but is similar to that of the Abyssinian species, but is less strongly pronounced; this structure is so very peculiar and difficult to describe, that reference should be made to the description of $H$. lividus as well. The elytra are similar, but appear more ivory-white in Mr. Marshall's specimens owing to their better preservation. They are much more strongly and deeply punctured than in the blue wing-cased species, and are also larger and longer in proportion. The head and thorax in the male are more opaque than in the female. The extreme base of the head (which in the specimens before me is sunk in the thorax) appears to be blackish, showing through the transparent front of the thorax, but the pronotum is unspotted in itself:

Ubs. It has been suggested that $H$. anceps, described on p. 81 (t. c.), is a synonym of $H$. superciliosus of Boheman. It is possible that that may prove to be so; but, apart from the fact that the three species I have distinguished are so closely allied that it would be perhaps impussible to say which of them should be referred to Boheman's insect from description alone, I beg here to protest against hasty assumptions on synonymy, especially by persons who have a very limited acquaintance with the group. I had, of course, studied Boheman before describing any of the Malachiidx, and the conclusion I came to was that I could not identify either of our insects with the species referred to.

Some other suggestions made prove on examination to be so wide of the mark, that I need only remark that they betray a want of acquaintance with the elements of the subject or a want of acumen in appreciating even crucial differences. 


\section{Melyris rufiventris, Bohem.}

Melyris rufiventris, Bohem. Ins. Caffr. i. fasc. ii. p. 479.

Hab. Mashonaland, Salisbury (Marshall).

Very close to $M$. corrosa, Reiche, and $M$. festiva, Reiche. Specimens which I have from Natal and these from Salisbury seem to differ in having the thorax more even, with the lateral carinæ straighter and not sinuate, or interrupted in the middle, and by the interstices of the elytra being less rugosely reticulate. The antennæ have the apical four joints wholly black; the three preceding these have the inner produced sides black, but are red externally, as the bases are. The legs with their coxæ are red, the claws alone being black.

Species of Melyris often occur in profusion when they are found; the four examples sent by Mr. Marshall were found on flowers of Protea.

\section{Fam. Erotylidæ.}

\section{Promecolanguria natalensis, sp. n.}

Sordide flava, elytris dilutioribus; antennis brevibus, articulis septem flavis subæqualibus, quatuor apicalibus nigricantibus; prothorace oblongo, convexo, lateribus sinuatis, basi bistrigato inter strigas transversim impresso; capite profunde, prothorace minutius et minus crebre punctatis.

Long. vix 6 millim.

Hab. Natal, Malvern, by beating Eugenia (Marshall).

Of the same size and very similar in general appearance to $P$. trogositoides, $G$., this insect is to be distinguished by several important characters. The head is rusty red; the antennæ are shorter, with only four or five joints at the apex black; the punctuation of the head is much deeper and more distinct than in that species. The thorax is quite of a different shape, being more convex, with depressed front angles, being, in fact, of the form common to Anadastus, and with deep short basal strigæ, and transversely impressed between them. At present $I$ have not referred species from Africa to Anadastus, but it is possible this insect may have to be transferred to that genus.

\section{Episcaphula picturata, sp. n.}

Oblonga, subparallela, nigra ; capite prothoraceque creberrime punctatis, hoc transverso, antice paullo angustato, angulis anticis et posticis acutis, maculis duabus, ad marginem anticam annexis, linearibus, undulatis, rufis; elytris brevissime pubescentibus, 
strigis duabus basalibus, nna humerali, una juxta medium, fasciisque tribus palde undulatis, tenuibus, nec marginem nec suturam attingentibus, prima humerum stibcingente, secunda pone medium, tertia subapicali rufis, his rufo-pubescentibus; antennarum articulis tertioad octavum fusiformibus, subequalibus, tertio parum elongato, clava elongata, articulis duobus ultimis subquadratis.

Long. 11-13 millim.

Hab. Mashonaland, Salisbury (Marshall).

The general form of this insect is quite that of the first section of the genus Episcapha, and the thin antennes with long joints in the funiculus, which also are pubescent, and an elongate club, of which the basal joint is obconic and the two following not wider than long, as well as the structure of the body beneath, quite confirm the opinion that it should be placed in Episcapha or Episcaphula. But it differs from all known African Episcaphula by the pattern, which on the elytra is almost exactly that of Triplatoma Gestroi, and also by not having the yellow abdomen, and by its short but rather thick pubescence.

The head is rather small, coarsely punctured, the eyes not much prominent, the canthus scarcely thickened nor conspicuous, their facets granular and rather coarse; the antennæ aie as long as the head and thorax taken together, with the mouth, palpi, \&c. wholly black. Thorax wider at the base than in front, opaque, confluently punctured, the sides narrow from the base, but are more suddenly narrowed at one third from the front angles, so as to seem almost angulated at that point ; their surface is on the whole even, but there is a wide depression on each side of the middle before the base; the basal margin is gently sinuate, the front almost truncate, with, however, slightly projecting acute angles; the base and front are not margined and the sides very finely so. The scutellum is triangular and transverse, finely punctured. The elytra are much more finely but closely and uniformly punctured, without series; very obsoletely subsulcate towards the extremities.

The general but superficial resemblance to some species of Triplatoma is heightened by the two short hamate streaks on the front of the thorax, and the markings of the elytra are so similar to those of $T$. Gestroi as at once to suggest that insect to one acquainted with Eastern Erotylida. It is to be noticed, however, that while the pubescence on the elytra generally is black, that on the red markings is of the same colour with them. The punctuation of the thorax beneath is very coarse, especially at the sides; the prosternal process is broad and emarginate at its tip, it is not compressed nor mucronate in 
front; the punctuation of the meso- and metasterna is finer and sparser, as is that also of the abdomen. The legs are long and thin.

Only two specimens were sent me by Mr. G. A. Marshall. They were captured at Edmond's Farm, Salisbury, under bark, in October 1898.

\section{Episcaphula aulacochiloides, Crotch.}

Episcaphula aulncochiloides, Crotch, Rev. Erotyl, Cist. Ent. i. 1876, p. 412.

Hab. Natal, Durban (Marshall).

Episcaphula interrupta, Lac.

Episcaphula interrupta, Lac. Mon. Erot. p. 56.

Hab. Natal, Malvern, Umfuli River (Marshall).

Amblyscelis natalensis, Crotch.

Amblyscelis natalensis, Croteh, Rev. Erotyl., Cist. Ent. i. 1876, p. 435 (Amblyopus).

IIab. Mashonaland, Salisbury (Marshall).

I have received this from Natal. Crotch records what is perliaps a distinet species from Lake Ngami.

It is best recognized by the elongate form and by being wholly yellow with the exception of the black elytra and black club of the antennæ.

\section{Amblyscelis nigrinus, Gorh.}

Amblyscelis nigrinus, Gorh. Ann. \& Mag. Nat. Hist. 1900, v. p. 83.

The habitat of the specimens labelled $7252-3$ should be Mashonaland, Salisbury, in fungi.

\section{Triplax vittipennis, Gorh.}

Triplax vittipennis, Gorh. Proc. Zool. Soc. 1889, p. 614, pl. Ixi. fig. 3.

Hab. Mashonaland, Salisbury, by sweeping, Nov. 1897 and Dec. 1898 (Marshall).

Four beautifully mounted examples of this insect are sent by Mr. Marshall. It was described from a specimen from Zanzibar. The Mashonaland examples are rather larger, two of them being respectively 6.5 and 7 millim. 'The yellow vitta is sometimes paler in colour than in the type and rather 
wider. The tibia are expanded sufficiently to bring the insect into the genus Amblyscelis; the type of that genus is A. Kelleni, a West-African species which has the three apical joints of the antennæ forming a connate club, with the joints transverse. As this insect with others, such as $A$. natalensis, has a long lax club, some further subdivision may be required. At present I regard the latter insect as forming a section of Amblyscelis only ( $c f$. 'Notes from Leyden Mus.' 1888, p. 144). The coarseness or fineness of the eyes is a much better character for the subdivision than the structure of the club, and is that which to a great extent differentiates Amblyscelis from Amblyopus, and which will also separate the Madagascar insects referred hitherto to Triplax (see also Gestro, Espl. del Giuba, Ann. Mus. Civ. Genova, 1895, p. 473).

\section{Dacne capensis, Crotch.}

Dacne capensis, Crotch, Rev. Erotyl., Cist. Ent. i. 1876, p. 397.

Hab. Mashonaland, Salisbury (" under bark," Marshall).

I possess this insect also from Natal, from Zanzibar, and several examples from the Upper Congo.

Crotch first mentions it under $I$. oequinoctialis, his opinion then being that it was "not a true Dacne" ; but his description made subsequently of $D$. capensis appears rather enigmatically immediately below, and by an oversight he omitted to mention the four red spots on the elytra. I have, however, examined the type, and it is the present insect, and of the same size, form, and general appearance of other small Dacnes. I see no reason for separating it.

\section{Aulacochilus capensis, Lac.}

Aulacochilus capensis, Lac. Mon. Erot. p. 251 ; Bedel, Ann. S. E. Fr. 1871, p. 284 ; Crotch, Rev. Erotyl, Cist. Ent. i. 1876, p. 480.

Hab. Mashonaland, Salisbury, in fungus (Marshall).

This interesting species, so closely allied to the other blue species which occur in Europe, N. Africa, and various parts of Asia, seems widely dispersed in South Africa. I have seen it from the Cape Colony (Drège), from Natal, and Zululand. It is (see Lac. l. c.) the Triplax capensis of Dej. Cat. 3rd ed. p. 453 .

[To be continued.] 